\title{
Commentary: Goal-directed or flow-directed perfusion?
}

\author{
Robert S. Kramer, MD, and Tyler Kelting, CCP
}

Magruder and colleagues ${ }^{1}$ have analyzed the relationship of oxygen delivery $\left(\mathrm{DO}_{2}\right)$ on cardiopulmonary bypass $(\mathrm{CPB})$ with regard to Society of Thoracic Surgeons (STS) outcomes in their article "Correlating Oxygen Delivery on Cardiopulmonary Bypass with Society of Thoracic Surgeons Outcomes Following Cardiac Surgery." Their analysis included 834 cardiac surgery cases (CPB, crossclamped). The lead author has previously published an experience showing an association between goal-directed perfusion (GDP) and a lower incidence of acute kidney injury (AKI) after cardiac surgery. ${ }^{2}$ Using an electronic perfusion record capturing real-time information during $\mathrm{CPB}$, including $\mathrm{DO}_{2}$ and flow parameters, the authors found that $\mathrm{DO}_{2}$ (threshold $280 \mathrm{~mL} \mathrm{O} / \mathrm{min} / \mathrm{m}^{2}$ ) was associated with the primary composite morbidity/mortality outcome (6 STS variables) not previously reported in the literature. They were able to capture potentially harmful exposures to low $\mathrm{DO}_{2}$, low flow, hypotension, or relative anemia and concluded that $\mathrm{DO}_{2}$ influences outcomes after cardiac surgery in addition to its known association with AKI.

This Magruder analysis strengthens the argument promoting the use of the GDP strategy. It helps us to understand how AKI could function as a surrogate for injury and dysfunction in other organ systems, as evidence shows that increasing severity and duration of AKI during the index admission are associated with poor immediate- and long-term outcomes that may not be directly related to renal failure. ${ }^{3}$ For the first time, these authors have shown that prolonged low $\mathrm{DO}_{2}$ is associated with both the STS morbidity/mortality metric

From the Division of Cardiovascular Surgery, Department of Cardiovascular Services, Maine Medical Center, Portland, Maine.

Disclosures: The authors reported no conflicts of interest.

The Journal policy requires editors and reviewers to disclose conflicts of interest and to decline handling or reviewing manuscripts for which they may have a conflict of interest. The editors and reviewers of this article have no conflicts of interest.

Received for publication Dec 15, 2020; revisions received Dec 15, 2020; accepted for publication Dec 16, 2020; available ahead of print Dec 25, 2020.

Address for reprints: Robert S. Kramer, MD, Division of Cardiovascular Surgery, Maine Medical Center, 22 Bramhall St, Portland, ME 04102 (E-mail: kramer@ mmc.org).

J Thorac Cardiovasc Surg 2022;164:1008-9

$0022-5223 / \$ 36.00$

Copyright (c) 2020 by The American Association for Thoracic Surgery

https://doi.org/10.1016/j.jtcvs.2020.12.075

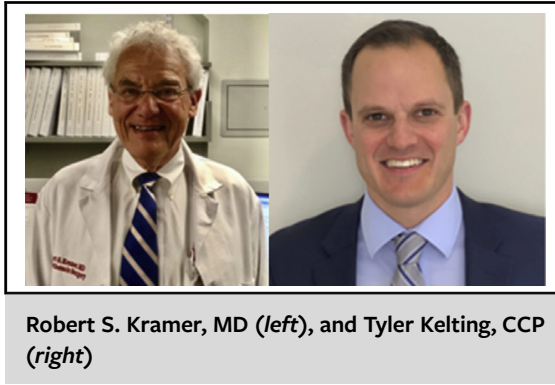

CENTRAL MESSAGE

The primary focus in goaldirected perfusion should be maximizing flow and minimizing hemodilution, with transfusion of red blood cells being the last resort.

and the prolonged ventilation $>24$ hours metric, along with what we already knew about postoperative AKI. In addition to showing that patients with anemia (present in more than $30 \%$ of cardiac surgery patients ${ }^{4,5}$ ) and low glomerular filtration rate are particularly vulnerable to these poor outcomes, the authors make 2 other important points about anemia: The first is that the comorbidities driving anemia ("anemia of chronic disease") are still present and not modified by intraoperative transfusions, and the second is that flow alone is often sufficient to reach greater $\mathrm{DO}_{2}$ targets.

The 3 variables of the $\mathrm{DO}_{2}$ formula are flow, hemoglobin, and oxygen. Adding blood to the pump may address the formula but not oxygen delivery at the tissue level, given the reluctance of stored red blood cells to give up oxygen. Accordingly, with regard to satisfying the $\mathrm{DO}_{2}$ formula, it is no surprise that flow is the backbone of the GDP strategy. While real-time calculations of $\mathrm{DO}_{2}$, are valuable, a focus on flow and limiting hemodilution rather than transfusing is crucial. Stored allogeneic red blood cells may satisfy the $\mathrm{DO}_{2}$ formula, but not the patient.

\footnotetext{
References

1. Magruder JT, Weiss SJ, DeAngelis KG, Haddle J, Desai ND, Szeto WY, et al. Correlating oxygen delivery on cardiopulmonary bypass with Society of Thoracic Surgeons outcomes following cardiac surgery. J Thorac Cardiovasc Surg. 2022; 164:997-1007.

2. Magruder JT, Crawford TC, Harness HL, Grimm JC, Suarez-Pierre A, Wierschka C, et al. A pilot goal-directed perfusion initiative is associated with less acute kidney injury after cardiac surgery. J Thorac Cardiovasc Surg. 2017;153:118-25.e1.

3. Brown JR, Kramer RS, Coca SG, Parikh CR. Duration of acute kidney injury impacts long-term survival after cardiac surgery. Ann Thorac Surg. 2010;90:1142-8.
} 
4. Fowler AJ, Ahmad T, Phull MK, Allard S, Gillies MA, Pearse RM. Meta-analysis of the association between preoperative anaemia and mortality after surgery. $\mathrm{Br} J$ Surg. 2015;102:1314-24.
5. Munoz M, Ariza D, Gomez-Ramirez S, Hernandez P, Garcia-Erce JA, Leal-Noval SR. Preoperative anemia in elective cardiac surgery: prevalence, risk factors, and influence on postoperative outcome. Transfus Altern Transfus Med. 2010;11:47-56.
See Article page 997.

\section{Commentary: Optimizing oxygen delivery during cardiopulmonary bypass to minimize morbidity and mortality: Have our goals been achieved?}

\section{Harold L. Lazar, MD}

Strategies involving goal-directed perfusion during cardiopulmonary bypass (CPB) have been associated with decreased acute kidney injury (AKI) following cardiac surgery. ${ }^{1}$ However, it is unclear as to what defines goaldirected perfusion during $\mathrm{CPB}$ and whether it can reduce not only AKI, but all morbidity and mortality in all patients undergoing cardiac surgery on CPB.

In this edition of the Journal, Magruder and colleagues ${ }^{2}$ report the relationship between oxygen delivery $\left(\mathrm{DO}_{2}\right)$ during CPB and morbidity and mortality in 834 cardiac surgery patients on CPB using an electronic perfusion medical record system (Quantum Perfusion Systems, Spectrum Medical, Fort Mill, SC) that provides continuous online data of flow parameters and hemodynamic variables, including $\mathrm{DO}_{2}$, blood pressure, cardiac index, pump flow, and hemoglobin $(\mathrm{Hgb})$. The institutional target for $\mathrm{DO}_{2}$ was at least $260 \mathrm{~mL} / \mathrm{O}_{2} / \mathrm{min} / \mathrm{m}^{2}$, which was achieved by optimizing flow parameters, reinfusing blood sequestered in the operative field, and transfusing blood products. The primary outcome was the occurrence of a composite of Society of Thoracic Surgeons (STS) morbidity/mortality outcomes (mortality, postoperative renal failure, surgical reexploration,

\footnotetext{
From the Division of Cardiac Surgery, Boston University School of Medicine, Boston, Mass.

Disclosures: The author reported no conflicts of interest.

The Journal policy requires editors and reviewers to disclose conflicts of interest and to decline handling or reviewing manuscripts for which they may have a conflict of interest. The editors and reviewers of this article have no conflicts of interest.

Received for publication Dec 5, 2020; revisions received Dec 5, 2020; accepted for publication Dec 7, 2020; available ahead of print Jan 21, 2021.

Address for reprints: Harold L. Lazar, MD, 80 East Concord St, Boston, MA 02467 (E-mail: harold.1.lazar@gmail.com).

J Thorac Cardiovasc Surg 2022;164:1009-10

$0022-5223 / \$ 36.00$

Copyright (c) 2020 by The American Association for Thoracic Surgery

https://doi.org/10.1016/j.jtcvs.2020.12.048
}

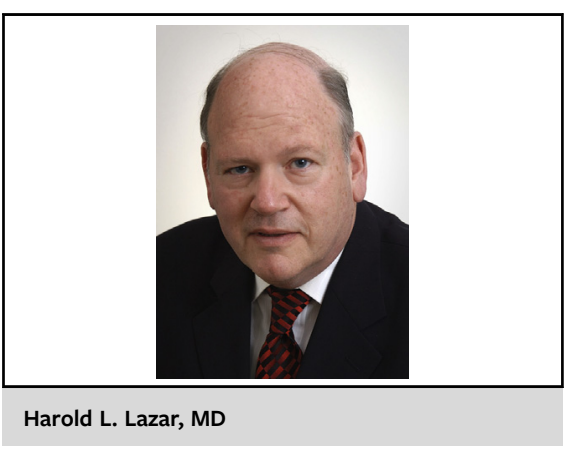

CENTRAL MESSAGE

Optimizing oxygen delivery during cardiopulmonary bypass may minimize morbidity and mortality.

postoperative prolonged intubation for $>24$ hours, deep sternal wound infection, and stroke). Although a $\mathrm{DO}_{2}<280$ was associated with an increased incidence of the composite STS outcome, the increase failed to reach statistical significance $(P=.07)$. However, in those patients undergoing nonisolated CABG procedures, a $\mathrm{DO}_{2}<280$ was significantly associated with the primary outcome $(P=.02)$. This was driven largely by an increased incidence of prolonged ventilation for $>24$ hours when the $\mathrm{DO}_{2}$ was $<280(P=.04)$. STSdefined renal failure was not associated with $\mathrm{DO}_{2}$ in the entire patient cohort $(P=.07)$; however, stage 1 AKI within 72 hours of surgery was independently associated with a $\mathrm{DO}_{2}<280(P=.02)$. Overall, patients with a preoperative glomerular filtration rate GFR $<65$ and a $\mathrm{Hgb}$ level $<12.5 \mathrm{mg} / \mathrm{dL}$ appeared to be most vulnerable for morbidity and mortality when the $\mathrm{DO}_{2}$ was $<280$.

This study has several limitations, which the authors have acknowledged. The sample size was relatively small, which limited the ability to determine causality. Data obtained during the period of weaning from CPB was included, which may have altered the outcomes. The interventions used to increase $\mathrm{DO}_{2}$ when values fell below 260 were not uniform. The database could not determine when patients were actively treated to maintain the target $\mathrm{DO}_{2}$, 